\title{
The "Woman" as a Frame for the Self: Femininity, Ekphrasis, and Aesthetic Selfhood in John Banville's Eclipse, Shroud, and Ancient Light
}

\author{
Mehdi Ghassemi
}

University of Lille, France

Copyright (c) 2018 by Mehdi Ghassemi. This text may be archived and redistributed both in electronic form and in hard copy, provided that the author and journal are properly cited and no fee is charged for access.

\begin{abstract}
Banville's latest trilogy Eclipse, Shroud, and Ancient Light forms an interconnected web of narratives that aptly dramatizes Banville's fictional investigation of subjectivity and otherness. The "other" in these narratives is consistently a female other on whom the narrators bestow a multitude of roles in their narcissist quests for authenticity. The "woman" is represented simultaneously as an enigma, the site of "truth", the guarantor of the narrators' authentic self, and the screen onto which the protagonists aim to inscribe their aesthetic signatures. This paper proposes to read these figurations in close relation with the theoretical undertone with which Banville engages throughout his philosophically imbued meta-fiction. It specifically addresses the way in which the figure of the "woman" becomes entangled with Paul de Man's elaborations on the "ontological crisis" in Romanticism as well as Friedrich Nietzsche's aesthetics of the "surface". Banville's fictional engagement with these thinkers, I claim, offers a way to read the narrators' ethical failure with regards to the key female characters as an aesthetic critique of ideology.
\end{abstract}

Key Words. Femininity, Truth, Framing, Subjectivity, John Banville, Eclipse, Shroud, Ancient Light

Resumen. La última trilogía de John Banville, Eclipse, Shroud y Ancient Light conforma una red interconectada de narrativas que acertadamente dramatizan la investigación del autor sobre la subjetividad y la alteridad en la ficción. El "otro" en estas narrativas es sistemáticamente un personaje femenino al que el narrador le confiere multitud de papeles en su búsqueda narcisista de autenticidad. La "mujer" es representada simultáneamente como un enigma, la sede de la "verdad", la garante del ser auténtico del narrador, y, por otro lado, como la pantalla en la que el protagonista pretende proyectar sus valores estéticos. Este artículo propone una lectura de estas figuraciones en estrecha relación con el trasfondo teórico que caracteriza la obra de Banville, una metaficción construida en parámetros filosóficos. Este trabajo analiza específicamente la manera en la que la figura de la "mujer" se ve envuelta en las formulaciones de Paul de Man sobre la "crisis ontológica" del Romanticismo, así como las 
teorías estéticas de Friedrich Nietzsche en torno al concepto de "superficie". Afirmo, pues, que el compromiso ficcional de Banville con estos pensadores ofrece una manera de leer el fracaso ético del narrador con respecto a los principales personajes femeninos como una crítica estética de la ideología.

Palabras clave. Feminidad, verdad, marco teórico, subjetividad, John Banville, Eclipse, Shroud, Ancient Light

\section{Introduction}

Many of Banville's novels can be read as accounts of the fascination of a male's tormented psyche with women. The female characters are simultaneously treated as objects of desire as well as objects of epistemological quest, figures that seem to encapsulate a crucial aspect of the narrators' journey of self-discovery. Several readings of Banville have identified the way in which female characters are reduced to abstract figures, and at times, even tools for the narrators' artistic aspirations. In the Art Trilogy, Elke D'hoker observes, the artistic metaphors the narrators use to depict women "serve the dual purpose of both containing ... and stripping" them of their agency (145-70). "These dehumanized women", Eoghan Smith claims, "are transformed into feminized objects of art, symbols of totalized presence subject to masculine gaze, touch and occasional violence" (110). Regarding The Book of Evidence, Anja Müller, in turn, examines the role of women in Freddie's visual narratives and argues that the latter's ekphrastic representations of the female other produces a "multi-layered discursive matrix for the materialization of the female body" (187). ${ }^{1}$

While almost all of the critical examination of Banville's "women" to date ultimately aims to raise the narrators' ethical shortcomings in dealing with the female other, I argue, the representation of the "woman" especially in the late trilogy (Eclipse, Shroud, Ancient Light) aptly illustrates Banville's ontological and epistemological vision of the self. This is particularly the case if these representations are read in relation to Banville's engagement with Paul de Man and Friedrich Nietzsche, whose writings underlie the entire trilogy. ${ }^{2}$ Focusing on Eclipse, Shroud, and Ancient Light, then, this paper aims at addressing the representation of the female characters and their role in Banville's philosophical agenda as well as his aesthetic project in his latest trilogy. The discussion is presented in three sections. In the first section, I examine the way in which the woman's body is posited as the site for "truth". This leads the female characters to be subjected to the narrator's phallic vision. In the second, I argue that the narrators' preoccupation with attaining pure aesthetic vision posit the female characters as artistic (re)creations. Here, I address how Paul de Man's idea of "ontological crisis" is given a new dimension in the trilogy, one that presents fundamental ethical concerns in Banville's aestheticism. Finally, in the third section, I argue that Nietzsche's aesthetic of the surface provides the narrators with a way out of the "ontological crisis" posited by de Man.

\section{Framing the "Woman"}

The protagonists' obsession with finding the true nature of their self and reality, that from which they are radically and agonizingly barred is seemingly intertwined with the "mystery" of femininity. In Eclipse, Lily "is an animate riddle that I have been set to solve" (123) and Lydia's "black hair" (34) confers upon her "an exotic" (34) feel. The radical unfathomability Axel associates with Magda and Cass in Shroud results in their depiction as uncanny "creatures", ones "who exist on a median plane between the inanimate and the super-animate, 
between clay and angels" (332). In Ancient Light, the narrator claims: "All women for me have an aura" (96). Harkening to the famous Freudian question - "what does the woman want?" - both Alex and Axel encounter the enigma of the woman's desire. The former expresses his inability to "solve the riddle" of Lydia's demand (Eclipse 31), and the latter literally reiterates the Freudian question in relation to Cass: "What did she want from him? She did not know" (Shroud 32). Moreover, as Ruth Frehner notes, women in Banville's fiction embody the "essential other" as they appear to possess what the narrators "lack" (53, 61). In the trilogy, the "essential" woman is fully exemplified by Lily and Cass in Eclipse. Even though Alex complains that Lily has intruded in his "solitude", she immensely captivates him: "At those moments of stillness and self-forgetting" when she "takes on an unearthly aura, exudes a kind of negative radiance, a dark light" (96). Having abandoned his family, he chooses to confine himself in his childhood house thinking that it is only via solitude that he is able to retrieve his true self. Nevertheless, it is through Lily that he can see what constitutes authenticity. Magda is Axel's "silent guarantor of authenticity" (Shroud 400) and Lydia is the constant "audience" for Alex's constant theatrical act, maintaining the coordinates of his narcissistic sense of self-presence (Eclipse 140). He laments the lack of "solid ground" and claims to have arrived at some sort of "centre" "through Lydia" (Eclipse $37)^{3}$

In Body Work, Peter Brooks identifies a tendency in the history of Western thought which implicitly designates the female body as a receptacle for truth. This, says Brooks, is coupled with the fact that the visual faculty as such has traditionally been regarded as the favourite means of knowledge-seeking: "sight has always been both a central faculty and a central metaphor in the search for truth" in that it "is conceived to be the most objective and objectivizing of the senses, that which best allows an inspection of reality that produces truth" (96). However, Brooks emphasizes, since access to truth is not straightforward, "it often is represented as veiled, latent, or covered, so that the discovery of truth becomes a process of unveiling, laying bare, or denuding" (96). On the one hand, the search for truth is intricately related to the female body, and on the other hand, "the point from which [epistemological] vision is directed at the world, has largely throughout the Western tradition been assumed to be male" (96). The "convergence of the erotic with the epistemic", thus, produces a "nexus" of "sight, knowledge, truth, and woman's body" in which "man as knowing subject postulates woman's body as the object to be known, by way of an act of visual inspection which claims to reveal the truth - or else makes the object into the ultimate enigma" (96-97). In her seminal text on the subject, Laura Mulvey, in turn, identifies "two contradictory aspects" of pleasurable looking. One "arises from pleasure in using another person as an object of sexual stimulation through sight" while the other is the pleasure derived from "identification with the image seen" (836). The first involves the "separation" of the subject's "erotic identity" from the image and the second implies the subject's identification with the image during what Freud calls primary narcissism (836-37). Since the second aspect is not immediately relevant for our discussion here, I will only address the first. To paraphrase Mulvey, since the socionormative Symbolic order traditionally attributes an active role to masculine identity, "the male figure cannot bear the burden of sexual objectification" (838). He is required to resist objectifying "his exhibitionist [male] like" because his own subjective position as male will also be threatened. As a result, his role, which is de facto designated "as the active one", must posit a woman as the object of his scopophilic vision for him to have a subjective position within the Symbolic order governed by phallic sexual difference (838). As a result, says Mulvey, women are assigned the "exhibitionist role" wherein their appearance becomes "coded for strong visual and erotic impact" so that "they can be said to connote to-be-lookedat-ness" (837). This, of course, has to do with the asymmetrical nature of human sexuation. Whereas men identify with the masculine signifier (which Lacan calls the phallus), an 
equivalent signifier that could represent femininity does not exist at the Symbolic level. Instead, women should identify with a signifier representing the lack of the phallus. This is not because women lack the penis due to biological reasons but, rather, it is because the sociosymbolic system that regulates human reality lacks a signifier that could posit them on a par with masculinity. Due to the traditional domination of women by men as well as the ensuing historical, ideological privileging of masculinity over femininity, the penis takes the form of an insignia of power, while the female genitalia is forced into a more passive position by not being identified with a signifier which can rival the phallus. Sexuality - and human reality as such, for that matter - becomes phallic, that is, based on the phallus as the only signifier available for acquiring a sexual identity. In her phallicized position, "the woman" comes to represent castration, hence she is perceived as threatening to man. ${ }^{4}$ Psychoanalytically speaking, the fear of castration paves the way for what can be called that phallocentric ideology that governs sexual identity. The figure of the castrated woman, the woman insofar as she lacks the phallus, constitutes the presence of the phallus as a "symbolic" presence (Mulvey 883) Therefore, says Mulvey, by objectifying her, the male gaze "circumvent[s] her threat", transforming her image into "raw material" for his active gaze (843). In a word, she is transformed into a "spectacle" (838).

The definitive characteristic of the representations of the "woman", especially in Ancient Light, is that they are carried out predominantly using visual imagery. Alex literally refers to the scene of his encounter with a woman riding a bike, whom he had probably mistaken for Mrs Gray, as a "spectacle" (Ancient Light 5). Later, he believes Mrs Gray's image offers him a "representation of woman in the raw" (29). His "goggling" eyes perfectly posit him as the male gazer into the scene of the passive woman offering herself as the image (5). Castration anxiety, ${ }^{5}$ the sort of anxiety so reminiscent of Freddie Montgomery's hysteric universe in The Book of Evidence, permeates Alex's perception of Mrs Gray to the extent that the instant her sexual desire acquires an active form it is perceived as threatening: she is described as shameless and "the spectacle of such raw desire threatened to have a deflating effect on me" (175). In the scene where he meets the woman on the bike, Alex is "fortuitously" given a "glimpse" into her "exposed" underwear (4-5). The word "fortuitously" portrays the scene as a lucky apparition of "a woman's nakedness" for the voyeuristic narrator, as if the disclosure of the "silken scantlings" (5) were the manifestation of a world that has hitherto been denied to him. He describes the sensation of accessing this world as "the sense I had of having been granted a glimpse into the world of womanhood itself, of having been let in, if only for a second or two, on the great secret" (6). The "secret" of "the world of womanhood", therefore, is linked to sight. He later attempts to salvage his account of the scene from being perceived as a vulgar episode of voyeuristic gratification: "What thrilled and charmed me was not just the sight I got of the woman's shapely legs and fascinatingly complicated underthings, but the simple, amused and generous way that she looked down at me, doing that throaty laugh, and the negligent, backhanded grace with which she subdued her ballooning skirt" (6). Nevertheless, in this very attempt at redemption he reveals that what fascinates him most is the mysterious combinatory gesture of gaze and laugh, which, to Alex, signifies the feminine "grace", the essential characteristic with which he describes Mrs Gray (6). A sublimated version of his bout of voyeurism, the latter functions as the embodiment of the feminine "secret". Womanly grace becomes the signifier by means of which he aims at fending off his fear of castration while, simultaneously, positing her body as a target for his visual avidity.

Brooks outlines different narrative strategies in representing the female body. In realist fiction, says Brooks, "Stories will very often, both in narrative structure and theme, concern curiosity directed at the concealed, clothed, hidden body" and "the very motive of representation" is the attempt at "seeing and knowing" which are ultimately attempts at 
"mastering" the female form. In modernist fiction, however, "the frustration of knowing produces a questioning of the epistemophilic project itself ... and the very principle of knowing - or of possessing - another body comes to appear hopeless" (105-06). With regard to Alex's depiction of Mrs Gray, it is safe to say that the representation of the female form fits into both categories. On the one hand, as we saw earlier, what sets Alex's narrative into motion in the early pages of the narrative is the "secret" world of femininity, and, on the other hand, he despairingly admits that Mrs Gray's entireness, "the total she", never stops eluding him (Ancient Light 46). Brooks singles out one "exercise of vision" which can grasp the totality of the female form, namely, still photography. Precisely by virtue of holding her "motionless", says Brooks, the artist is able to frame her wholeness. But, he points out, it is a murdering gaze: "the photographic gaze can see the body whole only by killing it" (102). Brooks convincingly gives examples of such a "photographic gaze" from nineteenth-century fiction. For instance, says Brooks, "we recall the ultimate coherence of Emma Bovary's body only when it has become inanimate" (102). This mode of narration, too, corresponds with the narrators' representations. ${ }^{6}$ In Shroud, Magda is a ghost, fixed, and "planted" (15); in Ancient Light, Dawn Devonport "was lying on her back with her hands folded" (166) and Mrs Gray is "sitting tailor-fashion with her ankles crossed" (60). More importantly, Alex admits that since his first encounter with Mrs Gray, he has been constantly trying to "fix her fully in my mind and make her of a piece" (47). Even at the level of narration the pronoun "she" at times seems a means for him to represent his fixed image of the woman rather than referring to an individual character: while talking to Billie, the latter asks him about the reason why Dawn Devonport might have tried to commit suicide, the word "she", seems simultaneously to stand for Mrs Gray, Cass, and Dawn Devonport: "I was confused for a moment, my mind having been off doing bold things with Mrs Gray, and thought she was referring to Cass ... I realized it was Dawn Devonport she meant" (149). Insofar as Magda, Cass, Kristina Kovac, and, of course, Mrs Gray all die, narration, then, aspires to be a process of stabilizing the undecidable, and fiction is set to function as fixion.

Indeed, the process inevitably fails. According to Brooks, the phallic body - the image of the woman "fixed" by the phallic signifier - "can never be wholly grasped as an understandable, representable object" because "the epistemophilic project is always inherently frustrated". As a result, "the investigatory gaze becomes fixated on an imaginary body" (Brooks 99), the phallic woman. This imaginary body, says Brooks, is knowable "only partially, metonymically, and fetishistically" (100). The totality of the body fails to yield itself to the epistemological gaze. ${ }^{8}$ The latter must content itself with "accessory details, metonymies of bodies", and "parts instead of wholes". This, says Brooks, leads to "metonymization within the field of vision" which is, in turn, translated into "the linear nature of the signifier". In other words, the bodily image must inevitably "unfold in sentences", whereby continually delaying "the final object of sight" (101-03). That is why in Ancient Light Mrs Gray's body appears to Alex "only as a series of disparate and dispersed parts" (46). In the bathroom, the mirror presents a peculiar image of her body:

What was presented to me was a triptych of her, a body as it were dismembered, or I should say disassembled. The mirror's central panel, that is, the central panel of the mirror on the dressing-table, if that is what it was, framed her torso, breasts and belly and that smudge of darkness lower down, while the panels at either side showed her arms and her elbows, oddly flexed. (30)

Far from a coherent image, Alex's visual apparatus at best yields an oddly fragmented form reminiscent of the female nudes à la Picasso. Moreover, his access to the female form is not direct, but mediated through a tripartite mirror. It is a "mirrored mirror" (29). Not only is his 
visual experience mediated through a mirror, but also the double mirroring reduplicates the image, resulting in a mise en abyme, thereby destabilizing the image and ceaselessly deferring the narrator's visual apprehension. The numerous punctuations - nine commas - together with the multiple use of phrases such as "that is" and "as it were" transcribe the deferral and lack of immediacy into the very fabric of the passage. In the following section I will demonstrate how, self-conscious of the mediated structure of his perception, the narrator sets to go beyond (or beneath) the medium and acquire direct access to the "woman-truth".

\section{Framing Mater(iality)}

In "The Inward Generation", Paul de Man, whose life and theories are central to Banville's trilogy, speaks of an "ontological crisis" that pushes the writer "back upon himself, in total inwardness, since any existence within the framework of accepted reality can no longer satisfy him" (Critical Writings 15). This, de Man explains, is due to the artist's "awareness of a deep separation" between one's "inner consciousness and the totality of what is not himself" (15), a gap that separates the subject from the object. This awareness results in a disquietude that forces the artist to turn inwards, so to speak, to seek solace in his or her own internal, imaginative capabilities in an attempt to attain "more primitive levels of experience" (142). According to de Man, this process of inwardness is "a pattern" which has been observed by artists since Romanticism (15).

In the case of Banville's trilogy, the rift between the subject and object is at the heart of the narrators' representations, arguably rendering these narratives Banville's most explicit expression of the ontological impasse. Faced with the inscrutability of what de Man calls the natural world, the narrators obsessively resort to the power of their imagination, rendering their narratives highly narcissistic if not solipsistic. "I am all inwardness", says Alex in Eclipse, "gazing out in ever intensifying perplexity upon a world in which nothing is exactly plausible, nothing is exactly what it is" (15). In Ancient Light, he wonders about his relation with Mrs Gray "with a sort of inward undulation" (188). Axel, in turn, "remarked inwardly again how uninsistent was the sunlight in this part of the world" (Shroud 17) and the smell of "ink paper dust provoked in [him] an inward sob of nostalgia" (Shroud 227-28).

Yet, it is not merely their own inwardness the narrators are interested in for their epistemological quest equally targets that of the female other. In Shroud, the narrative especially highlights Axel's fascination with Cass's interiority: "A faint, fast vibration came off her, as if there were something inside her spinning without cease at terrible, soundless speed" (95); "There was something wrong inside her" (312); "There was something to be desired, certainly, she felt it inside her" (32). The depictions conjure up the idea that Cass's "inside" contains a substance, an essence that will ultimately provide an answer to the narrator's epistemological predicament. That "something", it is further added, involves "the feeling ... of being newly pregnant" (32). The pregnancy metaphor, on the one hand, situates the essence the narrator seeks at the level of Cass's body, and, on the other hand, suggests that Cass is capable of giving birth to that essence. In effect, Axel does impregnate Cass and, by doing so, he literally reaches her "inside": "Even her nakedness would not be enough", says Axel, "I would open up her flesh itself like a coat, unzip her from instep to sternum and climb bodily into her, feel her shocked heart gulp and skip, her lungs shuddering, clasp her bloodwet bones in my hands" (107). Insofar as his narrative is concerned with shrouds, veils and hidden truths, the extremely violent imagery Axel deploys conjures up the idea that her "essence" lies beneath her skin, her last veil, one behind which there is no more masks, illusions, and slippery selves but sheer, raw matter. In psychoanalytic terms, it is the Real of Cass's body Axel is after, her "lungs" and "bones", 9 hoping to attain the access to reality from which he is barred at the Symbolic (deferred and mediated) level. In addition to penetrating 
her body, he penetrates and colonizes her mind: "What was not clear was whether the signs were really signs, and meant especially for her, or if they were parts of the thing itself, the thing for which she had no name, yet; those parts, that is, that she was to be allowed to see, to notice, to register" (194). The fact that the passage is narrated through the third person suggests a direct access into Cass's interior thoughts, one that provides a perspective into "the thing in itself", that which Axel precisely lacks. Through Cass's eyes he glimpse at "The pattern she had suddenly discerned", one that reveals "an infinitely more intricate order" (194-95).

In Ancient Light Alex uses similar, albeit less violent, imagery with regard to Mrs Gray: "I could only get into her from the outside, but [Billy], he had sprung from a seed and grown inside her, and even after he had shouldered his brute way out of her he was still flesh of her flesh, blood of her blood" (101). Alex links the Real ("flesh" and "blood") of Mrs Gray's body to the natural, "unmediated", relation her son, Billy, has with her, a relation Alex lacks because, unlike Billy, Alex did not spring from her "inside". This is why he "put[s]" himself "inside her" (49): "how accommodatingly she would spread herself on that filthy mattress and take inside her all my engorged fury, need and bafflement" (66). The word "bafflement" connotes Alex's confusion, lack of understanding and puzzlement with regards to reality while the fact that Mrs Gray welcomes that confusion "inside" her suggests that Mrs Gray's material interior holds the key for the narrator's epistemological predicament, thereby equating the sexual, bodily act with the intellectual quest for knowledge. In this sense, the narrators do not merely resort to their own inwardness, that is, their interiority and imagination, to find a way out of their epistemological crisis. They equally seek to bridge the gap between their subjectivity and the world by positing the female (material) body as the site for truth and simultaneously and physically reaching inside that body in an attempt to retrieve it. The fact that the narrator's search leads them to an encounter with the (Real) materiality of the other's body shows how de Man's idea of inwardness is given a nasty twist in the trilogy. This is indicative of the way in which Banville uses de Man's ideas in order to advance his own epistemo-aesthetic concerns.

Nevertheless, towards the end of his narrative, Axel admits: "I tried to put myself into her inner world, but ... I came only to an immemorial, childhood place, a region of accentless and unemphatic prose, exclusive haunt of the third person. She would not be known; there was not a unified, singular presence there to know" (Shroud 332). He realizes that beneath the surface there is no essence but the confusion and incomprehensibility of the Real. Far from attaining a "singular presence", his penetration of Cass (her body and mind) renders his own self spectral, transforming him into an insubstantial ghost. Speaking of Mrs Gray, Alex, in turn, says: "I had never been so sharply conscious of the presence of another human being, this separate entity, this incommensurate not-I; a volume displacing air, a soft weight pressing down on the other side of the bench seat; a mind working; a heart beating" (Ancient Light 35). The words "weight" and "pressing down" suggest a substantial materiality while "volume" suggests that this substance is enclosed within a container. At the same time, it is as if his access to the interior of this container is barred, transforming Mrs Gray into a radically "separate entity", one whose interiority is forever out of the narrator's reach.

According to Kant, insofar as the thing-in-itself cannot be accessible to the senses, one's phenomenal perception of the object acquires primary importance in aesthetic experience. This is why Kant considers the subjective apprehension of "the sublime" superior to the cognitive faculty of reason in dealing with matters artistic. This experience, says Kant, requires one to avoid "teleological judgements" in favour of a vision akin to the poet's: "one must consider the ocean merely as the poets do, in accordance with what its appearance shows" (Critique 152). Commenting on Kant's idea, de Man postulates: 
In this mode of seeing, the eye is its own agent and not the specular echo of the sun. The sea is called a mirror, not because it is supposed to reflect anything, but to stress a flatness devoid of any suggestion of depth. In the same way and to the same extent that this vision is purely material, devoid of any reflexive or intellectual complication, it is also purely formal, devoid of any semantic depth and reducible to the formal mathematization or geometrization of pure optics. (Aesthetic 83)

In other words, the aesthetic (poetic) seeing advocated by Kant requires one to resist the hermeneutic temptation to dig beneath and, instead, to stop at the surface. This, according to de Man, constitutes "material vision", "a pure aesthetic vision" in that it intends to be neither a "trope" nor a "symbol" (Aesthetic 82). In Ancient Light, in a scene of lovemaking between Alex and Mrs Gray, the latter suddenly metamorphoses into a photographic image the moment "her shoulder-blades were against the wall": "The belted gown agape at the top where I had been fumbling at it, and the skirts of it too were parted, bearing her bare legs to their tops, so that for a moment she was the Kayser Bondor to the life, as provocatively disheveled as the original was composed" (219).

He explains earlier that his "ideal" woman, "the Kayser Bondor lady", is in fact a poster, "a foot-high, cut-out cardboard beauty", which he sees set up in a female undergarment store (29). In a sense, the wall's flat surface in the depiction of Mrs Gray merges with the flat "cardboard" onto which the image of the Bondor lady is imprinted, transforming the visual perception of Mrs Gray into a two-dimensional surface figure. What is particularly highlighted in the description is the way Alex's teenage infatuation with the poster's "svelte" and "impossibly long legs" (29) is projected onto Mrs Gray's image and glosses over the reality of Mrs Gray's heftier built. The primacy of the poster's surface image over Mrs Gray's reality is accentuated in that the former is referred to as "the original", rendering Mrs Gray but a means for the enactment of his superficial, two-dimensional vision. The (probably rectangular) poster functions as a frame that enables Alex to fuse word and image and stage his aesthetic, superficial vision.

According to de Man, the Romantic poets tried to counter the nostalgia for the natural object by creating poetic images that differ from the natural world in an attempt to produce a representational (poetic) reality that is independent from the (inaccessible) world of natural objects. This is why in Romanticism, de Man writes, there is a simultaneous, systematic reverence of figurative language, on the one hand, and "a return to a greater concreteness, a proliferation of natural objects that restores to the language the material substantiality which had been partially lost" during the seventeenth century (Rhetoric 2 ). The poetic reality based on the image for the Romantic writer acquires an ontological status similar to the way in which the natural world is said to possess an ontological authority. In de Man's words, "Poets know of the act of naming - as implying a return to the source, to the pure motion of experience at its beginning" (Rhetoric 3). As for Banville's trilogy, Axel calls himself "an alchemist of word and image" (Shroud 62). Furthermore, the title of his book, "After Words" (77), is suggestive of the idea that Axel has theorized a new medium of representation, one which is not bound to linguistic referentiality and the epistemological predicament it entails. This is also true about Alex whose "method of learning off lines was to fix the text itself, I mean the very pages, as a series of images in my head, to be read and recited from" (Ancient 163). The depiction entails the literal transformation of text into an image, redefining the narrator's relationship with language: the Symbolic aspect of language (the metonymic flow of words in the signifying chain) is sacrificed in order to give way to a new experience of the text, one based on a purely Imaginary aspect.

Alex's ultimate attempt to engage in pure aesthetic vision and to bridge the gap between his self and the natural world, I claim, lies in his ekphrastic representations. The woman in 
Alex's world is either extremely colourful or "pale". On the one hand, in Mrs Gray he sees "umber", "rose", (127) "tiny splinters of gold", and "a turbid shade of bronze" (157). At times, the colours unite into producing a fully-fledged painting: "her body displayed, disconcertingly, a range of muted tints from magnesium white to silver and tin, a scumbled sort of yellow, pale ochre, and even in places a faint greenishness and, in the hollows, a shadowing of mossy mauve" (30). On the other hand, Alex is fascinated by the "exposed pale back" of Mrs Gray's "neck" (165). In Eclipse, Cass is Alex's "stark pale and tousled" daughter (126); Lily has a "pale long neck" (81) as well as thighs "pale as a fish's belly" (136); and Lydia has "delicate pale long feet" (16). What is evoked is the idea that the narrator imposes his colours on the woman as a clean slate, so to speak, the woman as a "pale", uncoloured canvas. He is not so much interested in representing her as much as he is obsessed with presenting his own - painted - versions of her. The act of painting Mrs Gray literally takes place for Alex when he administers lipstick to her lips (166). Earlier, he explains that as a teenager he "used to entertain" the thought "in which I was required to attend to certain cosmetic requirements of a grown-up woman. That woman was never specific but generic, woman in the abstract, I suppose, the celebrated Ewig-Weibliche" (166). Alex's claim that his interest in "the woman" lies primarily in her being "generic" and "abstract", that is, not a person but a mere figure for his aesthetic operation, equally sheds light on his metafictional and self-conscious references. They remind the reader that the descriptions are the makings of his mind's artistic eye, and they should be considered as such. ${ }^{11}$ Far from the sexual imagery with which Alex depicts her elsewhere, her subjectivity as an other (person) is completely eclipsed by her ability to contain Alex's visual, poetic aspirations, reducing her to a magical object whose surface emits a panoply of colours. In a word, more than anything, the narrator's primary interest in Mrs Gray is in recreating her surface effects.

Of Lydia, in turn, Alex says: "She turned, her head swathed in a swirl of ash-blue cigarette smoke, the garden's menacing greenery crowding in the window behind her, and, between the green, a patch of the sky's delicate summer azure. In this light the shock of silver in her hair was stark, undulate, ashine" (Eclipse 16-17). While the colours bring the visual surface to fore, the alliterative "s" highlights the auditory (thus, surface sensation) aspect of the image. What is more, the word "delicate" in the sense of fine texture intricately suggests touch. As T.J. Clark points out, "Painting has always prided itself on being, next to sculpture, the most object-oriented of the arts. A brushy surface is supposed to put the viewer directly in touch with things" (93). Alex's verbal painting of Lydia, in this sense, functions as a poetic image that aims at recreating the woman as a new object, one that is not only seen, but heard and touched as well. It is a pure aesthetic vision in Kant's sense in that the three senses "merely" (to use Kant's word) emphasize the phenomenal (surface). In fact, Alex's verbal painting embodies Clark's aesthetic object par excellence insofar as the aesthetic involves the moment when

the materiality of the sign is grasped again, and grandly played with, but precisely as "phenomenal substance", as part of a world of stuffs and perceptions. It is this tourniquet of the world's substance and the sign's substance, or better still, of the texture and structure of sentences, say, or metaphors, or passages of paint, and the texture and structure of experience. (100-01)

"Phenomenal substance" marks the narrators' dialectical attitude vis à vis appearance and reality. First they conceive of "substance" inside the woman to be reached via (physical and mental) penetration. Then, they realize that there is nothing inside but the chaos of the Real. And, thirdly, they rehabilitate her surface, hoping the latter will eventually yield ("display") 
the elusive substance they so vehemently strive to grasp.

\section{Framing the Self}

Insofar as Alex's ekphrastic representations of the woman aim at creating aesthetic objects, (verbal) paintings, they posit him as an artist in a manner reminiscent of Pygmalion - the mythological sculptor who fell in love with his sculpted woman, an inanimate object that was subsequently brought to life by divine intervention. ${ }^{12}$ In the case of Alex, however, the logic is reversed: the very living woman herself is turned into an artistic object, therefore, one can argue, mortified (frozen as a painting), rendered inanimate. In his reading of Rousseau's dramatization of Pygmalion, de Man argues that the statue is, in fact, a figure of "autobiography" (Allegories 175). That is to say, Rousseau's mise en scene of the myth is not so much about the representation of the magical power of art as it is an attempt by the artist to grasp a certain conception of the self. It is, to use de Man's words, "the teleology of a selfhood" in that it functions as a "symbiosis of the problems of understanding", on the one hand, and the questions "of selfhood", on the other (175). De Man's argument is in part based on the fact that, when he touches the statue, Pygmalion is "seized by terror". ${ }^{13}$ The "feeling of awe" that befalls the artist, de Man writes, is "transferred, by an act of the mind (sometimes called imagination) into the constitution of an entity, a subject, capable of reflecting upon the threatening power because it partakes of that power without however coinciding with it" (177). In this sense, the threatening feeling "actively involves the self" (177). This is where the words "menacing" (Eclipse 16) and "disconcertingly" (Ancient 30) in Alex's ekphrastic descriptions cited above become significant: in projecting feelings of threatening disquietude onto the painted image of the woman, he is, after all, aiming at involving his own self in the process, finding the way in which an aspect of his self reverberates through the surface of the verbal painting. Rather than, or, in parallel to knowing the other, in positing women as paintings the narrator seeks self-knowledge. The way in which the quest for self is inherently linked to the representation of the female other is evident early in Ancient Light where Alex speaks of the difficulty in remembering Mrs Gray's image as a whole:

I could remember her, certainly I could, but only as a series of disparate and dispersed parts ... I could hear her enraptured cries and smell her slightly eggy breath. But the woman herself, the total she, that was what I could not have over again, in my mind. And I, too, even I, there with her, was beyond my own recall, was no more than a pair of clutching arms and spasming legs and a backside frenziedly pumping. (46)

The word "too" is arguably the most revealing of the role of Alex's visual exercise in this narrative. The juxtaposition of Mrs Gray's fragmented image to the narrator's splintered selfimage suggests a correlation, an interdependence between the two images. By reproducing the "total" image of Mrs Gray Alex hopes to reproduce his own "total" image, to glue the sundered self back together using the other as a mirror for the self. ${ }^{14}$

"Painting", Banville says in an interview, "is the supreme art of the surface, and, as Nietzsche says, in the surface is where the depth is, and I believe that" (Banville, as quoted in Kenny, John Banville 53). As for Nietzsche, he famously championed the Greeks precisely because they knew how "to stop bravely at the surface, the fold, the skin; to worship appearance, to believe in shapes, tones, words - in the whole Olympus of appearance!" (Gay 8). "Those Greeks", Nietzsche says, "were superficial - out of profundity!" (Gay 9). In his rehabilitation of the surface, Nietzsche develops an aesthetic theory based on art as "good will to appearance", one that renders life tolerable in the aftermath of our "realization that delusion 
and error are conditions of human knowledge and sensation": "Honesty would lead to nausea and suicide. But now there is a counterforce against our honesty that helps us to avoid such consequences: art as the good will to appearance. We do not always keep our eyes from rounding off something and, as it were, finishing the poem" (Gay 107).

Through art, then, one can restore a sense of order from the chaos, one that would otherwise lead to destruction. At the same time, for Nietzsche, the structure of perception is doubly metaphoric in that it is based on the creation of images: "The stimulation of a nerve is first translated into an image: first metaphor! The image is then imitated by a sound: second metaphor!" ("On Truth" 144). Based on this, he stresses the importance of artistic creation. Insofar as perception is metaphoric, changeable, therefore, malleable, it offers a great potential for aestheticization. The aestheticization of experience, in turn, offers a way out of the deadlock that separates the subject and the object: "between two absolutely different spheres, such as subject and object are, there is no causality, no correctness, no expression, but at most an aesthetic way of relating, by which I mean an allusive transference, a stammering translation into a quite different language" ("On Truth" 148). This "different language" advocated by Nietzsche is precisely what Alex's ekphrastic representation is about. In fact, ekphrasis has two functions for Alex's philosophical preoccupation: firstly, it enables him to bridge the gap that bars his access to the inscrutable other through the aesthetization of his visual perception. Secondly, it functions as a means for the narrator to restore his own problematic sense of self. In this sense, he sacrifices "the woman" as a human being with an interiority in order to find a Nietzschean solution to the Kantian problem. By means of framing the woman, he strives to frame a sense of order in the orderless world. He counters the mise en abyme produced by his unreliable perception by a mise en cadre of the aesthetic surface, a surface that can posit him as its creator.

This view of the relationship between the artistic self and the female other inevitably raises serious concerns with regard to the ethical catastrophe propagated in the narratives, a concern that has already been voiced by critics such as Eoghan Smith and Patricia Coughlan. For the former, there is a "concern about the degree to which the Banvillian motif of the artwork's 'presence' reinforces gender binaries rather than disturbs them" (112). Smith here arguably touches upon the most problematic issue in the trilogy, one that seemingly cannot exonerate Banville's highly self-reflexive and self-conscious narratives. "Despite the irony, satiric representation of solipsism, and postmodern de-substantiating", Coughlan, suggests, in turn, Banville's fiction "leaves some foundations undisturbed", they "project the [feminine] other as an outside, as a space of ideological escape from Western rationality" (97-98). Nevertheless, at least two points are to be considered before reducing Banville to an ideologue of male chauvinist hegemony. Firstly, in addition to the abstraction of women into receptacles for the narrator-artist's quest for authenticity, what these narratives foreground is the crucial dependence of the self on the other. If the self as such is to be grasped as a positive entity, it needs to be articulated in relation to an other. That is to say, if the other is excluded from the equation, no self can be found no matter how creative the narrators are. This is why their narcissistic quest inward ultimately fails to yield any conceivable sense of self; they are bound to turn to the other, their narcissistic shell has to be opened. In this sense, Banville's fiction is an exploration of the alterity at the heart of any subjectivity, of the fact that the self is never self-contained. Secondly, insofar as sexual difference is based on the asymmetric way in which masculinity and femininity are phallicized through the Symbolic, Banville's narratives can be regarded as an examination of how masculine-feminine intersubjectivity functions, how it is constructed, rather than a promotion of the phallic structure of male and female identities. This is precisely in line with his own claim that "art is always the world itself, the description of the world, the description of the surface of the world, and this is one of the reasons I started to be interested in paining, as a way of writing, as something to write 
about" (qtd. in Kenny, John Banville 53). The narrators' ethical disaster is to be considered along the idea that Banville's narrative art is an elaboration on the way in which reality is constructed (here the reality of male chauvinistic ideology) rather than the advocation for moral responsibility. Specifically, if art functions as a mirror-surface of the world, it lays bare its inherent ideological premises. This is one function of de Man's "aesthetic ideology": art as the locus in which the very textual apparatus of perceptions and representations are rendered palpable (McQuillan 88).

In Shroud, Axel writes his autobiography using the symbolic pen given to him by Cass (396). This is the pen into which Cass had meticulously hidden a photo of the narrator and the original Axel, showing, to the narrator's awe, that she had known his deepest secret all along. The pen in Shroud can be viewed as Banville's central, multilayered metaphor in his tripartite narrative of representation. Insofar as the pen represents writing, it is related to the text. But it is a pen that contains Axel's photo, his image. It is, one can claim, the artist's magical sceptre, the brush with which he can fuse writing and painting, word and image. The pen can equally stand for language, textuality, the very medium via which he seeks to recapture his self. In situating the photo that reveal Axel's truthful past inside the pen, Banville accentuates the idea that, if there is "truth" to be found, it is in the medium itself, that truth can neither be attained via the movement inwards nor in the penetration of the other. Rather, it is the penetration of the pen itself that can reveal the truth: the unified self is but an illusion and one's access to it is always barred by the very medium that constructs it. Nevertheless, the medium, the pen, can be used to recreate the self as an artist and the fact that the pen is not Axel's own but Cass's illustrates the crucial role of the other in the process of selfaestheticization.

\section{Notes}

${ }^{1}$ Besides Müller, other critics such as John Kenny ("Well Said Well Seen”, 2000), Joakim Wrethed ("A Momentous Nothing", 2014) and, especially, Joseph McMinn ("Ekphrasis and the Novel", 2002) have also written about ekphrasis in Banville's fiction. McMinn's essay, specifically, reads Banville's oeuvre as an example of the way in which the novel as a distinctly modern form is able to engage in ekphrasis as a practice traditionally reserved for poetry.

${ }^{2}$ De Man's influence is especially noticeable in Shroud where Banville partly bases Vander's controversial past on that of de Man's.

3 "I had come from nowhere, and now at last, through Lydia, I had arrived at the centre of what seemed to be somewhere" (Eclipse 37).

${ }^{4}$ Elizabeth Grosz nicely paraphrases Lacan's idea of phallus as a signifier. According to Grosz, the problem lies in the fact that the biological difference between male and female genital organs "becomes expressed in terms of the presence or absence of a single (male) term" (Jacques Lacan 117). This, in turn, results in the penis to be "removed from its merely anatomical and functional role within ("natural') need [...] to the role of object" (11617). As a result of the "misappropriation of the penis by the phallus" men have a positive signifier to identify with whereas women have to situate themselves in a position related to the absence of a signifier rather than a signifier of their own (117). Castration in the psychoanalytic sense, means being stripped from the phallus as the signifier and, thus, being objectified.

${ }^{5}$ Hedwig Schwall points out that all of Banville's narrators demonstrate excessive fear of castration ("Mirrors" 118).

${ }^{6}$ Kenny continues: "Banville has reviewed and commented upon far more books to do with photography than any other of the visual arts, and with increasing frequency in his later periods" (John 57).

7 Here, Brooks draws heavily on Freud's theory regarding the child's psycho-sexual development. Freud postulates that the scopophilic drive is inherently linked to the desire for knowledge. Brooks nicely paraphrases Freud's idea: "the drive to know originates in the child's perception of the anatomical distinction between the sexes, and in the overwhelming question addressed to the world, and to its parents: Where do babies come from?" Since the child's question never receives a satisfactory answer from the parents, his/her epistemological 
quest only becomes "displaced" engendering a permanent feeling of frustration that is to say with the individual's later development. It also defines one's sexuality as such (99).

${ }^{8}$ This, Brooks explains, is due to the intrusion of an excess in the field of vision: "the perception of an unrationalizable sexual difference, the insistence that the missing object of the investigatory glance is present everywhere". As a result, "the object [of representation] in itself undergoes a repression that then charges substitute objects with a greatly increased affect" (101-02).

${ }^{9}$ He uses a similar language regarding Kristina: he can feel "her meagre flesh and the soft-seeming rib-cage beneath" (Shroud 155).

10 “'Did you put yourself inside her?' [the priest] asked. 'I did, Father,' I answered” (Ancient 49).

11 Along these lines one can also consider how Mrs Gray often appears as a receptacle for the narrator's elaborate metaphors. Mrs Gray's simple departure from home to meet Alex is described as "skimming towards me on her half-shell, wafted by the full-cheeked zephyrs of spring" (12) and her figure as "a moving silhouette outlined in burning gold" (191), to give but a few examples.

${ }^{12}$ Ralph Hertel identifies a similar process in Athena, where "A" "comes into life under the loving gaze of the Pygmalion-like narrator" (38). Hertel reads the parallel as part of the Frames narrator's attempt to fuse "life and art" (38).

13 "I don't know what I feel in touching this veil; I am seized by terror" (Rousseau as quoted in de Man, Allegories 176).

${ }^{14}$ In a recent interview, Banville traces the historical as well as contemporary ill treatment of woman to "what men think" about women and, especially, how these conceptions have been internalized by women themselves ("People Think").

\section{Works Cited}

Banville, John. Eclipse. London: Picador, 2000.

. Shroud. London: Picador, 2002.

Ancient Light. London: Penguin, 2012.

"Many People Regard me as a Misogynist". The Journal. 4 October 2017. 2 December 2017. http://www.thejournal.ie/john-banville-interview-mrs-osmond3625663-Oct2017/

Brooks, Peter. Body Work: Objects of Desire in Modern Narrative. Cambridge, MA: Harvard University Press, 1993.

Clark, T.J. "Phenomenality and Materiality in Cézanne". Material Events: Paul de Man and the Afterlife of Theory. Ed. Tom Cohen et al. Minneapolis: University of Minnesota Press, 2001. 93-113.

Coughlan, Patricia. "Banville, the Feminine, and the Scenes of Eros". Irish University Review 36.1 (2006): 81-101.

De Man, Paul. Allegories of Reading: Figural Language in Rousseau, Nietzsche, Rilke, and Proust. New York : Columbia University Press, 1979.

- The Rhetoric of Romanticism. New York: Columbia University Press, 1984.

- Critical Writings: 1953-1978. Ed. Lindsay Waters. Minneapolis: University of Minnesota Press, 1989.

—. Aesthetic Ideology. Ed. Andrzej Warminski. Minneapolis: University of Minnesota Press, 1996.

D'hoker, Elke. Visions of Alterity: Representations in the Works of Banville. Amsterdam: Costerus, 2004.

Frehner, Ruth. "The Dark One and the Fair: John Banville's Historian's of the Imagination and their Gender Stereotypes". BELLS 11 (2000): 51-64.

Grosz, Elizabeth. Jacques Lacan: A Feminist Introduction. New York: Routledge, 1990.

Hertel, Ralph. Making Sense: Sense Perception in the British Novel of the 1980s and 1990s. Amsterdam: Rodopi, 2005. 
Kant, Immanuel. Critique of the Power of Judgement. Trans. Paul Guyer. Cambridge: Cambridge University Press, 2000.

Kenny, John. "Well Said Well Seen: The Pictorial Paradigm in John Banville's Fiction". Irish University Review 36.1 (2006): 52-67.

_. John Banville. Dublin: Irish Academic Press, 2009.

McMinn, Joseph. "Ekphrasis and the Novel: The Presence of Paintings in John Banville's Fiction". Word \& Image: A Journal of Verbal/Visual Enquiry (W\&I) 18.2 (2002): 13745.

McQuillan, Martin. Paul de Man. London: Routledge, 2001.

Müller, Anja. "You Have Been Framed: The Function of Ekphrasis for the Representation of Women in John Banville's Trilogy (The Book of Evidence, Ghosts, Athena)". Studies in the Novel 36.2 (2004): 185-207.

Mulvey, Laura. "Visual Pleasure and Narrative Cinema". Film Theory and Criticism: Introductory Readings. Eds. Leo Braudy and Marshall Cohen. New York: Oxford University Press, 1999. 833-44.

Nietzsche, Friedrich. "On Truth and Lying in a Non-Moral Sense". The Birth of Tragedy and Other Writings. Trans. Ronald Spiers. Cambridge: Cambridge University Press, 1999. 139-53.

- The Gay Science. Trans. Josephine Naukhoff. Cambridge: Cambridge University Press, 2001.

Schwall, Hedwig. "'Mirror on Mirror Mirrored is all the Show': Aspects of the Uncanny in Banville's Work with a Focus on Eclipse". Irish University Review 36.1 (2006): 11633.

Smith, Eoghan. John Banville: Art and Authenticity. Oxford: Peter Lang, 2013.

Wrethed, Joakim, “A Momentous Nothing': The Phenomenology of Life, Ekphrasis and Temporality in John Banville's The Sea". The Crossings of Art in Ireland. Eds. Ruben Moi, Brynhildur Boyce, and Charles I. Armstrong. Bern: Peter Lang, 2014. 183-211.

Mehdi Ghassemi is currently Adjunct Lecturer on English at the University of Lille where he previously completed a $\mathrm{PhD}$ in English Literature in "co-tutelle" with KU Leuven. His research revolves around the relation between subjectivity and style in the works of John Banville and Jacques Lacan, with additional interests in Henry James and Friedrich Nietzsche. He has publications on Banville's novels with Etudes Irlandaises, Re-Imagining Ireland, Mosaiques, and Irish Journal of Gothic and Horror Studies.

ghassemi.me@gmail.com 